\title{
Die skuldgebed in Esra 9:6-15
}

\author{
Pieter M Venter \\ Departement Ou-Testamentiese Wetenskap \\ Universiteit van Pretoria
}

\begin{abstract}
The penitential prayer in Ezra 9:6-15

The penitential prayer is a traditional Gattung used in ancient Israel. The prayer of Ezra 9:6-15 bears all the characteristic marks of this genre. In this prayer a historical scheme and themes such as "the land" are used to depict the Judean community's sin. In a study of its literary structure, macro narrative context and socio historic background, this article shows that the confession in the prayer in reality is a liturgical strategy to proclaim Yahweh's righteousness in his relationship with his people. Rather than imploring God, the community of faith expresses its belief in God and their identity as God's own people in this prayer.
\end{abstract}

\section{INLEIDING}

Die skuldgebed, of boetegebed ("penitential prayer") in die Ou Testament vertoon 'n eiesoortige struktuurpatroon. Dit kan as 'n selfstandige literêre genre beskou word. Volgens Werline (2003:3) se definisie van die skuldgebed is dit 'n Gattung met "a direct address to God in which an individual, a group, or an individual on behalf of a group confesses sins and petitions for forgiveness as an act of repentance." Volgens Boda (1999:28) bestaan hierdie Gattung uit die volgende elemente:

- Lofprysing.

- Versoek aan God waarin die nood gestel word en gevra word vir bevryding daarvan.

- Belydenis van skuld waarin aanspreeklikheid aanvaar word en skuld in solidariteit met die voorgeslagte erken word.

- Historiese oorsig waarin die verlede gebruik word om die kontras tussen God se liefde en Israel se oortreding uit te beeld.

- Temas, soos die verbond, die land en die wet.

- Die doel van die gebed om 'n einde te bring aan die gevolge van die sonde, hetsy dit gevangenskap, onderdrukking of haglike omstandighede is. 
Die genre van die skuldgebed kom voor in verskillende plekke in die Ou Testament. Dit kom ook voor in buite-Bybelse literatuur van dieselfde tyd as die Bybel. Skuldgebede staan opgeteken in 1 Konings 8:22-52, Esra 9:6-15, Nehemia 1:5-11, Nehemia 9:6-37, Psalm 106, Daniël 9:4-19 en in die buiteBybelse 1 Barug 1:15-3:8.

Een van die kenmerke is dat 'n historiese oorsig gebruik word. In die meeste van hierdie skuldgebede kom so ' $n$ historiese oorsig voor. Daar is egter ook baie ander plekke in die Ou Testament waar 'n oorsig oor die geskiedenis gebruik word, maar waarin dit nie oor skuldgebede gaan nie. Voorbeelde hiervan is Deuteronomium 32:1-43, Daniël 2:1-49, 7:1-28 en 11:14, Psalms 78, 105, 135 en 136, Esegiël 16 en 20, Ekklesiastikus 44-49, die Dierevisioen in 1 Henog 89:59-90:19, die Apokalips van die Week in 1 Henog 93:1-10, Tobit 14:4-7, Kaïro Damaskus Dokument 1:3-12, 2:14-4:12, 5:20-6:11, Jubileë 1:7-18 en 23:13-21. In die oorgrote meerderheid van hierdie gevalle word dieselfde historiese skema gevolg.

Hierdie historiese retrospeksie bevat verskillende elemente of geskiedenisfases. Dit wil voorkom of hierdie patroon deel is van 'n beskouing oor Israel se verlede wat met verloop van tyd geyk geraak het en aanvaar is as die algemeen aanvaarde opsomming van die geskiedenis. Die patroon sluit die elemente in van skepping, aartsvaders, uittoggebeure, woestyntog, verblyf in die land, ballingskap en terugkeer na die land. Nie al hierdie elemente word elke keer gebruik wanneer die geskiedenis opgesom word nie. Die skuldgebede van Esra 9:6-15, Nehemia 1:5-11, Nehemia 9:5b-37, Psalm 106 en Daniël 9:4-19 kan as voorbeeld gebruik word.

\begin{tabular}{|c|c|c|c|c|c|}
\hline & Esra 9:6-15 & Neh 1:5-11 & $\begin{array}{l}\text { Neh 9:5b- } \\
37\end{array}$ & Psalm 106 & Dan 9:4-19 \\
\hline Skepping & & & 6 & & \\
\hline Aartsvaders & & & $7-8$ & & \\
\hline Uittoggebeure & & & $9-11$ & $7-12$ & 15 \\
\hline Woestyntog & $10-12$ & & $12-21$ & $13-33$ & \\
\hline $\begin{array}{l}\text { Verblyf in die } \\
\text { land }\end{array}$ & & & $22-31$ & $34-42$ & \\
\hline Ballingskap & 7 & $6 b-9$ & $32-35$ & & $5-14,16-19$ \\
\hline Terugkeer & $8-9,13-15$ & $10-11$ & $36-37$ & & \\
\hline
\end{tabular}

Hierdie historiese oorsig oor Israel se geskiedenis is in wese 'n strategie wat gevolg word om in terme van dit wat gebeur het oor God en sy volk te teologiseer. Uit die geskiedenis word dit duidelik wie die Here is en wie Israel is. Deur die bepaalde skema wat gevolg word, word God en Israel in hulle wedersydse verhouding geskets. Teologiese konseptualisering word hier in terme van verhoudingsbegrippe gedoen. Hierdie relasie-aanduiders word hier 
spesifiek in terme van historiese gebeure gedefinieer. Wanneer die historiese skema in die vyf skuldgebede in Esra 9:6-15, Nehemia 1:5-11, Nehemia 9:5b37, Psalm 106 en Daniël 9:4-19 gebruik word, is dit ' $n$ teologiese strategie om daardie verhouding wat in historiese terme gedoen is nog verder te verfyn in terme van Israel se skuld voor God en sy genade oor sy volk. Ons het hier met teologiese kleinkuns te doen waarin historiese konseptualisering die toon aangee. Hierdie opmerking is van kardinale belang wanneer ons na ander aspekte van die skuldgebed kyk.

Wanneer daar na ander aspekte van die skuldgebed gekyk word, moet daar noodwendig ook uitbreidings of modifikasies daarin aangebring word. So is dit byvoorbeeld met die verbond. Die gevestigde siening onder navorsers is dat die skuldgebed met 'n situasie te doen het waarin dit oor die verbond met God gaan. Dit is egter nie in alle gevalle so nie. Boda (1999:40) het aangetoon dat die enigste gemeenskaplike situasie in al hierdie gebede ' $n$ godsdienstige geleentheid is waarop daar doelbewus niks geëet word nie (religieuse vas). Die inhoude van die gebede verwys almal na plekke en tye waarop daar om godsdienstige redes gevas is. As gevolg van die omstandighede na afloop van die ballingskap het die klem verskuif na gereëlde vasdae in die Judese gemeenskap. Uit die Deuteronomistise en priesterlike Esegiël tradisies het 'n gebedstradisie ontwikkel waarin die Gattung van die skuldgebed op sulke vasdae gebruik is om skuld voor God te bely en by Hom te smeek om verandering te bring in hulle onbehaaglike omstandighede. Wat opvallend is in die gebede, is wat Boda (1999:41) noem hulle "dominant personal perspective". Dit is elke keer ' $n$ individu wat die gebed bid namens die Judese gemeenskap. Dit lyk dus geregverdigd om 'n meer beperkte situasie te veronderstel waarin die individu die leiding neem en in solidariteit met die geloofsgemeenskap namens hulle skuld bely en hulle afhanklikheid van God erken.

Wanneer na die situasie van hierdie vyf skuldgebede gekyk word, is daar telkens ' $n$ individu aan die woord. Daar is egter ook elke keer ander mense by die gebed betrokke. Daar is ook duidelik 'n groter liturgiese konteks. In die geval van Psalm 106 dui die lofprysing aan die begin en einde op 'n moontlike liturgiese geleentheid. Dit word egter nie uitdruklik gesê nie. In die geval van Nehemia 1:5-11 is dit 'n persoonlike gebed wat Nehemia gebid het voordat hy die koning genader het om toestemming te kry om saam met sy volksgenote na sy land terug te gaan. In die geval van die ander drie het ons uitdruklik met liturgiese situasies te doen. Die gebed in Esra 9:6-15 word "daar" (9:4) voor die tempel (10:1) teen die tyd van die aandoffer (9:4-5) gebid. Die gebed in Nehemia 9:5b-37 word op die byeenkoms vir die vasdag (9:1) gebid. Die gebed in Dan 9:4-19 word in Jerusalem gebid gedurende die 
tyd van die aandoffer (9:21), terwyl die tempel self nog vervalle en ontwy is. Die spesifieke verbinding van die laaste drie gebede aan kultiese tye en liturgiese geleenthede, plaas hulle in 'n eie kategorie.

In die lig van die bepaalde tipe teologisering wat in hierdie gebede voorkom (soos ek dit hierbo uiteengesit het) en die uitdruklike verbinding aan die liturgie in die laaste drie gebede, wat sopas hier bo genoem is, kan belangrike perspektiewe op die teologiese inhoud van die skuldgebed in die Ou Testament geopen word. Dit kan op sy beurt ' $n$ wesentlike bydrae tot die besinning van die skuldgebed in die Christelike erediens lewer. Aangesien ek elders reeds aan die gebed in Nehemia 9:5b-37aandag gegee het (vgl Venter 1995, 1999), asook aan die gebed in Daniël 9:4-19 (Venter 2004), spits ek my hier toe op die gebed in Esra 9:6-15. ' $n$ Verdere rede is dat daar baie minder oor hierdie gebed gepubliseer is as oor die gebede in Nehemia en in Daniël. 'n Oorsig oor die werksaamhede van die werkgroep van die Society of Biblical Literature, bekend as "Penitential Prayer: Origin, Development, and Impact Consultation", wys duidelik uit dat hierdie gebed nog nie sy regmatige aandag gekry het nie.

\section{DIE SKULDGEBED IN ESRA 9:6-15}

Verskillende aspekte van die skuldgebed in Esra 9:6-15 word ondersoek. Die eerste aspek is die genre van die gedeelte. Daarna word op sinkroniese vlak gekyk hoe hierdie genre as raamwerk gebruik is om die gedeelte te konstrueer. Dit word dan binne die literêre makrokonteks van die EsraNehemia vertelling ondersoek. Die tweede laaste stap is 'n ondersoek na die sosio-historiese konteks waarin die gebed geskep is. Laastens word die teologiese betekenis van die gebed verwoord.

\subsection{Genre}

Soos hierbo aangedui, het Boda (1999:30) aangedui dat die genre van die skuldgebed ("penitential prayer") gekenmerk word deur sy gebruik van tipiese elemente soos lofprysing, smeking, belydenis van sonde en sake soos verbond, land en wet. Buiten die saak van die verbond, is al hierdie genoemde elemente pertinent teenwoordig in die gebed in Esra 9:6-15. Soos in die historiese skema hierbo uiteengesit, kom die elemente van woestyntog, ballingskap en terugkeer ook in hierdie gebed voor. Die historiese skema wat in hierdie gebed gebruik word, fokus op die bewoning van die land vanaf die vaders (mytt ba ymym, 9:7) tot op die hede (vandag hzh $\mu$ whh , 9:7, 9:15). Alhoewel "die land" die samebindende faktor in hierdie trajek van Israel se geskiedenis is, lê die klem wesenlik op die wet van God wat gewaarsku het teen die misbruik van die land deur ondertrouing met die ander inwoners van 
die land. Die sentrale motief van hierdie deel van die geskiedenis is dus die gebeure tydens die bewoning van die land met die gevaar van afgodery wat ondertrouing met die ander inwoners van die land noodwendig meebring. Dit was waarteen Moses hulle uitdruklik gewaarsku het voor hulle die land binnegetrek het (vgl Deut 7:1-4). Dwarsdeur die verloop van hierdie bepaalde deel van die geskiedenis was die ander inwoners met hulle afgode 'n bedreiging vir die Israeliete. Hulle het voor hierdie versoeking geswig en hulle kinders met die heidense volke laat ondertrou. Daardie sonde word nog steeds gedoen in die tyd van Esra.

Die tradisionele genre van skuldbelydenis word dus in hierdie gebed gebruik om in terme van oortreding die Naam van God te bely. Die geykte historiese skema word ingespan om die verhouding met God in terme van skuld in die gebed tot uitdrukking te bring. Binne hierdie historiese skema word dan pertinent gefokus op die land wat bewoon, verbeur en weer herwin is. Hierdie fokus op die land is ' $n$ opsigtelik teologiese tegniek om die geaardheid van Israel te beskryf. Die land in die verloop van Israel se geskiedenis was nog altyd die geografies-temporele katalisator wat hulle wesenlike geaardheid ontbloot het en hulle aan die man gebring het as mense wat ongehoorsaam is aan hulle God. So word die skuld wat in hierdie gebedsvorm bely word, nader gepresiseer in terme van oortreding van die Here se voorskrifte.

Die uitdruklike verwysings in Esra 9:8-9 en 9:11-14 na eietydse omstandighede, maak dit volgens Williamson (1998:33) "too specific ... to have been an independent prayer inserted in its present position by a later editor who thought that it might be appropriate." Die gebed was 'n integrale deel van die komposisie reg van die begin van die skryf daarvan af. Die tradisionele Gattung van die skuldgebed is gebruik, maar opsigtelik aangepas deur die keuse van die elemente wat hier bo aangedui is, om binne sy bepaalde literêre raamwerk in te pas. Die uniekheid van die gedig word nog duideliker wanneer die struktuur daarvan ontleed word.

\subsection{Die struktuur van die gebed}

Die genre van die skuldgebed is saam met die geykte historiese skema gebruik om Israel se skuld in terme van die land te beskryf. In die struktuur van die gebed kan dieselfde tegniek gesien word. Dit het 'n simmetriese struktuur. In sy omraming gaan dit oor skuld in die algemeen. Binne hierdie omraming fokus dit op ondertrouing met ander volkere van die land as verbesondering van daardie skuld. Die inligting daaroor staan in die kern van die struktuur. Dit kan grafies soos volg uiteengesit word: 
9:6-7 Ons skuld is sedert ons vaders geweldig groot. As gevolg daarvan het ons in die ballingskap die konings van die aarde ten prooi geval.

9:8-9 Die Here het ons laat vrykom en aan ons vastigheid in Jerusalem gegee. 9:10-12 Ons het $u$ wette oortree. Ons het nie geluister na u gebod om nie met die inwoners van die land te ondertrou nie.

9:13-14 Die Here het ons laat ontkom. Hoe durf ons hierdie genade in die wind slaan deur tog met ander te ondertrou? God sal dit terugtrek.

9:15 Die Here is reg. Die Here het 'n res laat oorbly vir vandag. Ons is totaal skuldig.

In die omramende gedeelte (9:6-7 en 9:15) word die sonde van Israel in algemene terme gestel sonder om dit nader te omskryf. Die begrippe "sondes" (t nWl ) en "misdaad" ( $\mathrm{m}[\mathrm{a}$ ) word gebruik in 9:6, 7, 13, 15. Die inhoud van die oortreding word nie hier uitgespel nie. Daar word gewoon gesê dat die sonde geweldig groot is (9:6), dat dit al sedert die dae van die voorouers by hulle aanwesig is (9:7), dat dit die oorsaak is dat hulle aan die "konings van die land" (t wK $r$ a h yk I m) uitgelewer is (9:7), dat dit die oorsaak is vir alles wat met hulle gebeur het (9:13) en dat die Here ten spyte daarvan tog nog 'n res van hulle laat oorbly het $(9: 13,15)$. Israel se sonde omvat nie net 'n lang tyd nie ("van die voorvaders af"), maar omvat ook almal wat aan die volk behoort. Teenoor die verindividualiseringtendens in Esegiël, staan almal hier in hulle gemeenskaplike sonde in solidariteit met mekaar. Dit word ook in die volgende gedeelte uitgedruk met die term "land", waar Israel as 'n enkele entiteit teen die ander volke in die land afgespeel word.

In die sentrale gedeelte (9:10-12) word die inhoud van Israel se sonde pertinent in terme van die oortreding van God se wet (t wK $m)$ uitgespel. Hierdie wet word nog nader bepaal deur dit uitdruklik aan die land te verbind ( $A \mathrm{r}$ a $h$ ) (in 9:11 twee keer en in 9:12 een keer). Die profete het uitdruklik gewaarsku dat die land besoedel is ( $h d n)$ deur sy inwoners met hulle gruwels ( $h b[$ wt ). As Israel op enige wyse met hulle assosieer of met hulle ondertrou, word hulle self deel van hierdie besoedeling. Hulle sal dan alle seggenskap op die land verbeur.

Deur die loop van sy geskiedenis het Israel hierdie uitdruklike opdrag voortdurend bly oortree. Hulle het inderdaad met die inwoners ondertrou. Hulle het weer by 'n situasie uitgekom soos hoeveel maal in die geskiedenis waar dit duidelik word dat dit deel van hulle geaardheid is om teen die wetlike voorskrifte in met nie-Israeliete te trou. Daardeur het hulle alle seggenskap op die land verbeur. Hulle staan deur al die jare tot selfs vandag ( $h$ zh $\mu$ whh ) skuldig voor God (twee keer in 9:7, 9:15c) en is skuldig aan die oortreding van 
hierdie uitdruklike voorskrif. Dit is die gevolge van hulle oortreding dat hulle met hulle konings en priesters in die hande beland het van "die konings van die lande" ( $t$ w r a h yk I m, 9:7). Hulle is doodgemaak, gevange geneem en geplunder. Hulle het slawe geword, onder andere van die koning van Persië $(9: 8,9)$. Hulle het hulle land verloor, hulle onafhanklikheid en selfs hulle selfrespek. Daarvoor moet hulle volle verantwoordelikheid aanvaar en hulele skud voor God bely.

Ten spyte van dit alles geniet hulle nogtans bepaalde voorregte. Dit word uitgedruk met twee begrippe. Eerstens het daar 'n "res" (9:15) van hulle oorgebly. Tweedens geniet hulle "vastigheid" (9:9) deur verblyfreg in Jerusalem.

In die literêre struktuur van die gebed kom hierdie twee begrippe voor in die eenhede 9:8-9 en 9:13-14. Hierdie eenhede staan binne die raamwerk van die algemene belydenis van skuld in 9:6-7 en 9:15, maar vorm saam weer die raamwerk vir die pertinente formulering van die ondertrou-oortreding in die sentrale fokuspunt van 9:10-12.

In kontras met hulle skuld oor die algemeen en spesifieke sonde van ondertrouing en dus verbeurdverklaring van hulle seggenskap op die land, staan die onverdiende genade aan die volk van wie daar darem nog 'n res oorgebly het, wat ontkom het. In albei gedeeltes (9:8-9 en 9:13-14) word die status van Israel aangedui as die wat ontvlug het en oorgebly het $(h f y l p, r a \square$, 9:8, 9:13, 9:14).

Die vastigheid wat Israel geniet ten spyte van hulle oortreding, word in 9:8-9 temporeel-religieus-geografies uitgedruk. In die lang geskiedenis van oortreding en straf het daar 'n tussenpose ([ gr Af [ mk, 9:8) gekom vir Israel waarin hulle weer vastigheid kon kry. Vir die kort tydsduur van 'n enkele moment in die loop van die geskiedenis, het sake vir hulle anders geword. Die vastigheid ( $d t y, 9: 8$ ) wat daar gekom het, word geografies aan Jerusalem en Juda (9:9) verbind. By die heiligdom van God het daar verankering gekom. In die herbou van die huis van God, die herstel van die ruïnes daarvan en die herstel van die verdedigingsmuur van die stad (9:9) ervaar hulle hulleself as die res wat ontkom het en oorgebly het en wat vir 'n tydjie weer rus gevind het. Alhoewel hulle slawe was en dit nog steeds is, het daar 'n ligpunt in hulle slawerny gekom toe hulle religieus aktief kon word om die tempel en die stad te herbou. Hulle het weer begin lewe en asem geskep (letterlik: hulle oë is verlig en hulle slawerny is vir 'n oomblik opgehef 9:8).

Teen die tafereel van die land dus met die wisseling van bewoningafwesigheid daaruit, sien Israel deur die oë van Esra hulleself as mense wat dwarsdeur die geskiedenis skuldig was omdat hulle deur ondertrouing nie aan God se wette getrou gebly het nie. Aan die ander kant is hulle tog die "res" 
wat ontkom het, die groepie wat vastigheid het, wat slawe is, maar tog die ruimte geniet om religieus in Jerusalem aktief te wees. Hierdie kontras tussen veroordeeldes, maar tog begenadigdes, word teen die agtergond van hulle verhouding met Jahwe verwoord. Hierdie oënskynlike teenspraak is moontlik vanweë die bepaalde tipe verhouding waarin hulle met die unieke God Jahwe staan.

Meer nog, die situasie van "ten spyte van" word juis gebruik as teologiese manier van praat om uit te spel wie Jahwe is. Die onlogiese ervaring om terug te keer na die land wat hulle eintlik verbeur het, om bevry te word en oor te bly na die straf van die ballingskap, om weer vastigheid te vind, om voort te gaan met die diens by die tempel, onderstreep dat die Jahwe wat daar agter sit, hulle straf maar hulle ook genadig is en vir sy volk verposing verskaf. Hy is die God van geregtigheid ( $h t$ a gydx, 9:15). Dit is nie bloot geregtigheid "with forensic overtones" (Williamson 1998:35) nie, maar die uitdrukking van 'n tipe verhouding waarin die "partners" nie gelykelik presteer nie. In sy optrede om te straf, maar ook te red, word die grootsheid van Jahwe duidelik. Al loop Israel die gevaar om met die voortsetting van hulle jarelange geneigdheid om te ondertrou selfs ook hierdie verposing wat God vir hulle gebied het te verbeur, kan hulle nogtans saam met die belydenis van hulle skuld ook hulle geloof bely dat Jahwe uniek is in sy straf-genade verhouding met sy volk. Al het hulle alle aansprake op God se liefde verbeur, is Jahwe nog steeds die God wat Hy altyd was wat sonder enige teenprestasie vir sy mense omgee (vgl Williamson 1998:36). Skuldbelydenis is hier in wese geloofsbelydenis van God.

\subsection{Die literêre raamwerk}

Die literêre benadering tot die boek van Esra worstel basies met twee vraagstukke. Die eerste vraag gaan oor die outeurskap. Wat is die verbintenis met die boek Nehemia en veral met die boeke Kronieke? Die vraag wat gevra word, is of alles deur een en dieselfde outeur/outeurs/skool geskryf is of deur verskillende persone/groepe ( $\mathrm{vgl}$ Farisani 2004). Die tweede vraagstuk is of Esra en Nehemia een deurlopende vertelling is of nie.

lemand soos Kraemer (vgl by Eskenazi 1993:75) gaan daarvan uit dat dit twee afsonderlike komposisies is. Esra 1-10 is 'n priesterlike ideologie wat op die herstel van die kultus en die tempel fokus. Nehemia verteenwoordig dan die teenoorstaande, selfs 'n anti-tempel ideologie. Esra se gebed verteenwoordig volgens hierdie standpunt dus 'n priesterlike ideologie teenoor Nehemia se gebed in Neh 9:5b-37 wat eerder anti-tempel sou wees.

Eskenazi (1993:74) redeneer na die ander kant toe. Sy sien EsraNehemia "as a literary artifact in which diverse sources combine meaningfully 
to express particular ideologies". Die boeke vorm vir haar saam een deurlopende vertelling wat opgebou is rondom die drie sentrale temas van "geloofsgemeenskap", die "huis van God" en "skriftelike tekste". In navolging van Bremond verdeel Eskenazi (1988) Esra-Nehemia in drie dele. In Esra 1:14 word die doel van die gebeure gestel. Die geloofsgroep moet 'n "huis vir God" gaan bou. In Esra 1:5 tot Nehemia 7:72 word van die proses vertel waardeur hierdie opdrag uitgevoer word. Die derde deel in Nehemia 8:1-13:31 gaan oor die feesviering van die projek wat suksesvol afgehandel is.

In meer besonderhede bestaan Eskenazi se tweede deel uit ' $n$ inleiding (Esra 1:5-6), 'n eerste beweging om die opdrag uit te voer (Esra 1:7-6:22), 'n tweede (Esra 7:1-10:44) en 'n derde beweging (Nehemia 1:1-7:5) en 'n terugskou (Neh 1:7-5). Volgens hierdie skema van Eskenazi kom die gebed dus spesifiek in die tweede beweging van die tweede hoofdeel (Esra 1:5-Neh 7:72) voor.

Volgens die drie sentrale temas wat sy geïdentifiseer het, sien Eskenazi die gebed eerstens as deel van die opdrag om weer 'n geloofsgemeenskap op die been te bring. Die mededeling wat Esra ontvang het, dat daar sommige is wat met nie-Judese vrouens getroud is (Esra 9:1-2), belig een van die kernprobleme in die herstel van die geloofsgemeenskap. Om heilig te wees is nie net 'n saak wat priesters en Leviete raak nie, maar die hele gemeenskap. Die gebed stel dus volgens Eskenazi die saak van unieke Judese identiteit aan die orde: "Becoming a holy people ....is at stake." Wat belangrik is, is dat die hele gemeenskap in die gebed ingesluit word. Dit betrek al die gelowiges by die belydenis van skuld en die aksie om weer die gemeenskap op te bou om heilig vir God te wees. Volgens Eskenazi (1988: 68) se interpretasie is die gebed binne die verhaalraamwerk Esra se " address ... to God, but the book makes clear its impact on the people. The community is affected, and it is from the community that a course of action issues."

Die verwysing van Esra in sy gebed na die "vastigheid" wat hulle tydelik geniet (9:8, w $\square d q \mu$ gq mb dt y - letterlik: tentpen in sy heilige plek), is vir Eskenazi (1988:72) ' $n$ aanduiding dat meer op die spel is as net ' $n$ fisiese tempel wat herbou moet word. Die huis van God as die tempel, is reeds voltooi. Die versugting wat in die gebed uitgespreek word, is dat ook die huishouding van God herstel sal word.

Vanuit haar literêre benadering bring Eskenazi die gebed dus in verband met twee van die hooftemas in die verhaal. Die gebed het vir haar in die literêre opset veral met die gemeenskap te doen. Sy maak baie daarvan dat die gebed 'n sosiale konteks het wat in die ontvouing van die verhaal na vore kom. In die proses beklemtoon sy die sosiale konteks, maar onderspeel myns insiens die saak van die kultus. Die verhaalraamwerk van die gebed is 
ten nouste aan die kultus verbind. Toe Esra hoor dat die Israeliete en priesters met ander volke ondertrou het, reageer hy daarop met die tipiese rourites deur sy klere te skeur, sy hare en baard uit te trek en te vas (9:4). Hy begin met die boetegebed wanneer dit tyd is vir die aandoffer (9:4-5). Hy doen sy gebed by die tempel (10:1). Hy gee onmiddellik daaraan 'n kultiese konnotasie.

Throntveit (1992) se literêre benadering lees die Esra-Nehemia verhaal as die uitbeelding van drie paralelle terugkere: onder Serubbabel (Esra 1-6), Esra (Esra 7-10) en Nehemia (Neh 1:1-7:3). Die gebed van Esra is "the theological high point of the book that bears his name" (Throntveit 1992:52). Die gebed staan dan ook in die deel oor Esra se terugkeer (Esra 7-10). Die gebed self is simmetries gestruktureer (soos hier bo by die struktuur aangetoon), maar is volgens Throntveit nog verder omraam met die narratiewe optrede van Esra se treuraksies in Esra 9:3-5 en 10:1a. Buiten dat die inhoud van die gebed opsigtelike homiletiese kenmerke vertoon, staan dit binne die raamwerk van kultiese handelings. As "pure confession laced with strong homiletic overtones" (Throntveit 1992:54) is die gebed gerig op die kultiese situasie. Dit is nie soseer gerig op 'n versoek om vergiffenis nie, as eerder om die situasie en die wat daaraan deelneem in ' $n$ bepaalde rigting te stuur. In Throntveit (1992:54) se woorde "'the prayer doth also preach' and confronts the people with the judgment of grace."

Die konteks vir die teologiese inhoud van die skuldgebed is dus primêr hier die kultus. Die intellektuele raamwerk van 'n opdrag om gemeenskap, tempel en woord van God in Eskenazi se terme in ere te herstel, of om in Thronveit se idioom terug te keer om die gemeente weer te kom opbou, vorm die agtergrond van die gebedsepisode. Die gebed speel in op die liturgiese situasie waarin die gemeenskap betrek word.

Die verbinding tussen skuldgebed en gemeenskap in die verhaal moet egter teen die agtergrond van die skrywerswêreld verstaan word. Veral die inhoud wat hy/sy/hulle in die vertelling aan die gebed gee in verhouding met ' $n$ gemeenskap wat hier kulties opgeroep word tot bepaalde aksies, moet ondersoek word. Eskenazi het in haar literêre benadering baie klem gelê op die verhaal as 'n literêre konstruksie wat bepaalde historiese impulse gehad het. Die verhaal moet as genre verstaan word "... as a literary category with a specific relation to extratextual phenomena” (Eskenazi 1993:76). Die literêre konstruk moet dus ook binne sy bepaalde sosio-histories konteks verstaan word. 


\subsection{Die sosio-historiese konteks}

Die skuldgebed van Esra speel in 'n kultiese konteks af. Holmgreen (1987:67) sê ook van Esra: "His acts have cultic significance." Die gebed self word kulties veranker. Die vastigheid wat God gee, is geknoop aan die tempel (WDd q $\mu$ ng mb , 9:8). God het die Persiese koning oorreed om hulle toe te laat om die tempel van God te herbou, dit uit sy ruïnes te laat herrys (9:9) en om self voor God te kom staan (9:15). Die positiewe waardering van hulle huidige situasie word ook aan Jahwe verbind. Die klein tydjie van genade wat hulle ervaar kom van Jahwe af (wyhl a h why $t$ a $m, 9: 8$ ). Hierdie verposing word in 9:8 uitgebrei met vier werkwoorde. Hulle word aangebied in die infinitivus vorm met telkens 'n voorgevoegde lamed om 'n ABAB-patroon van alternatief enersklinkende woorde te vorm: $r$ ya $\square h \mid$, wl At $t \mid w, r$ yahl, wht $t$ w. Dit is Jahwe wat 'n klompie van hulle laat ontkom het, wat vir hulle vastigheid by die tempel gegee het, wat hulle weer laat lewe het (vgl Nuwe Afrikaanse Bybelvertaling 1983) en wat aan hulle tydelike verligting van hulle slawerny gegee het.

Daarteenoor staan die dreiging dat hulle dit alles kan verloor. As hulle God se wette oortree en weer soos in die verlede met nie-Jode trou, sal God geregverdig wees as Hy in sy woede hulle geheel en al vernietig sodat daar niks sal oorbly van die res wat ontkom het en die wat ontsnap het nie ( $h f y l p w$ t yr a $\square \div$.ja $h \mid k A d[$, 9:14). Hy sal met ander woorde selfs die huidige tydelike gunstige posisie totaal tot niet maak. Hierdie dreiging lê volledig opgesluit in die Judeërs se moontlikheid om hulleself te vernietig.

In die navorsing na die sosio-ekonomiese strukture van die Persiese provinsie Juda gedurende die vyfde-vierde eeu vC en die boeke EsraNehemia as reflektering van hierdie tyd, kom verskillende moontlikhede na vore (vgl Eskenazi 1993:66-71). Wanneer die Juda van daardie tyd volgens Weinberg (1992) se siening as Bürger-Tempel-Gemeinde gesien word waarin sosio-ekonomiese belange geïntegreer is met godsdienstige affiliasie om landregte en burgerskapstatus te verseker, kan ondertrouing tussen verskillende groepe vanuit daardie hoek bestudeer word. Blenkinsopp (1991) se teorie dat die teruggekeerde groepe bepaalde gedragspatrone uit die ballingskapsituasie op die gemeenskap oorgeplant het en gebruik het om grond in die hande te kry en beheer oor die tempel oor te neem, dui die moontlikheid aan van tussengroepkonflikte in die wedywering om 'n magsposisie in die gemeenskap. Ekonomiese en demografiese verskuiwings het met die terugkeer van groepe onder verskillende persone soos Sesbassar, Serubbabel, Esra en Nehemia plaasgevind.

Die bedreiging wat die gebed in ondertrouing sien, kan verstaan word as teenkanting teen 'n politieke maatreël wat die Persiese owerheid ingestel 
het, ' $n$ etniese suiweringbeleid van die owerheid, 'n misoginiese houding in Juda soos dit reflekteer word in Spreuke 1-9 en Jesus ben Sirag, maatreëls gebaseer op die erfreg bepalings by Elafantine uit die vyfde eeu vC en selfs ' $n$ konflik tussen die vroulike profeet Noadja en Esra (vgl Eskenazi 1993:77-78 vir die verskillende moontlikhede). Die interne motivering van Esra om die gemeenskap te herstel was ook primêr religieus. Hoewel huwelike met vrouens van ander volkere nie per se verbode was nie, het dit volgens Deuteronomiese denke wesenlike gevaar vir die outonomiteit van Jahwisme ingehou. Die rede vir sy optrede kon dus allereers godsdienstig-kultureel gewees het (vgl Boshoff 2005:12-13).

Wie ook presies die volk van Israel (l a r $\square \mu[h)$, die priesters en Leviete in Esra 9:1 is, wat hulle nie afgeskei het van die nie-Joodse bevolking (t w r a h ym[ ) nie, is ook nie duidelik nie. Grabbe (1998:32) beskou die name wat vir hierdie "volk van die land" gegee word as simbolies vir die volkere met wie Israel te doen gehad het toe hy die eerste keer in Kanaän gekom het. Dit is vir hom te betwyfel of daar nog sulke mense in daardie tyd in die Judese gebied was.

Terwyl die identifisering van hierdie "volk van die land" oop is vir teoretisering, is dit interessant dat Grabbe hulle mede-aandadig maak vir die dreigende verlies wat die Judeërs in die gesig staar. Volgens Grabbe (1998:34) erken Esra nie net die sonde van Israel in die verlede en hede nie, maar plaas hy die blaam "squarely at the door of the inhabitants of the land with whom Israel should never had mixed". Dit is die gruwels van hierdie inwoners wat Israel onrein sal maak en die oorsaak sal word dat hulle die nuut verwerfde vryheid weer sal verloor.

Dit is te betwyfel of Grabbe korrek is om hierdie "volk van die land" in die beskuldigdebank te plaas. Dit gaan in die gebed eerder om die volk van Israel met sy priesters en Leviete wat met hierdie mense ondertrou. Esra se gebed is daarop gerig om die groep wat met hom assosieer oor te haal om sy definisie van die groep se identiteit te aanvaar en daarvolgens op te tree. Tollefson \& Williamson (1992:49) het aan die hand van Wallace se sosiokulturele antropologie aangetoon dat daar in 'n proses van kulturele heropbou ses dinge gebeur:

- Die leier identifiseer die wantoestande in die gemeenskap en skryf dit toe aan die oortreding van bepaalde reëls. Volgens sy insig kan daar net herstel kom as bepaalde voorskrifte gevolg word om hierdie reëls in ere te herstel. 
- Hy propageer sy maatreëls in die openbaar as die oplossing vir die wantoestand wat hy in die gemeenskap uitgewys het. Die mense wat hy tot sy standpunt oorhaal begin hom volg en self ook sy visie aan ander te propageer.

- Die "bekeerdes" word in 'n organisasie saamgesnoer wat hierdie visie in die kleiner kring van hulle gemeenskap begin uitleef.

- In die aanpassingsfase begin die groep met ander bestaande groepe in konflik kom. In die proses ondergaan die oorspronklike visie die nodige aanpassings om dit vir die breë gemeenskap aanvaarbaar te maak.

- In die kulturele transformasiefase aanvaar die hele gemeenskap die siening wat aan hulle voorgehou is. Hulle implementeer dit dan met behulp van verskillende programme wat gevolg word. Hierdie maatreëls ruim dan die aanvanklike wantoestande wat tot die visie aanleiding gegee het, uit die weg.

- Wanneer die beweging daarin slaag om die teenstand in die gemeenskap te oorkom, spanning op individuele en sosiale vlakke te verlig en die visie realisties by omstandighede aan te pas, word hulle siening die algemeen aanvaarde patroon. Die visie word dan deel van die daaglikse lewenspatroon van mense en word deel van die ekonomiese, sosiale, politiese en godsdienstige lewe van die gemeenskap.

Terwyl Tollefson \& Williamson (1992:49) hierdie teorieë op die Nehemiaverhaal toegepas het, is dit waar dat dit net so van toepassing op die gebed van Esra kan wees. Sy gebed is in wese die program waarin hy die gevaar wat die gemeenskap bedreig, identifiseer en die terapeutiese stappe uitspel om dit af te weer. In sy geval lê die probleem konkreet by die ondertrouing van die groep wat hy vir homself idealiseer en ' $n$ ander groep wat nie sy standpunte deel nie. Dit kan 'n groot deel van die Judese bevolking wees of selfs ander inwoners van die streek wat nie dieselfde godsdiens beoefen het nie. In die proses wil hy 'n groep om hom versamel wat hierdie standpunt deel en uiteindelik die gemeenskap oorhaal om dit die algemeen aanvaarde standpunt van die bevolking in Juda te maak. Sy program moet uitkring vanaf die liturgiese byeenkoms van die wat na sy standpunt oorgehaal is na die al groter kring van die gemeenskap wat hulle identiteit in terme van die inhoud van die gebed sien. 
Hierdie standpunt wat Esra huldig is nie noodwendig identies met die van Nehemia nie. Nehemia 13:23-31 gaan ook oor ondertrouing. Die gebed van Esra 9:6-15 verskil egter in sommige opsigte van die van Nehemia 9:5b37. Daar is ' $n$ belangrike verskil in byvoorbeeld, die houding teenoor die Persiese koning in die twee gebede van Esra en Nehemia (vgl Williamson 1987:88-89). In Esra se gebed word die herstel van die tempel toegeskryf aan die gunstige houding van die Persiese koning, waartoe God hom oorgehaal het (vgl Esra7:6, 27-28; 9:9). Daarteenoor verwys Nehemia 9:36-37 in die Nehemiagebed na Israel wat slawe is in hulle eie land. Hulle staan in diens van buitelandse konings wat God oor hulle aangestel het. Hier is glad nie sprake van 'n tempel wat herbou is nie (vgl Esra 9:9). Dit sny die teoretiese moontlikheid af dat die Nehemiagebed van die persoon Esra of sy Esramemoirs afkomstig is (vgl Williamson 1998:26). Dit sluit selfs die moontlikheid oop dat die Nehemiagebed "may have originated in the circle of those Judaeans who were never sent into exile in Babylon but who continued to live in Palestine" (Williamson 1987:26). Dit hang op sy beurt saam met die vraagstuk oor wie eerste was, Esra of Nehemia (vgl Williamson 1987:55-68 vir die bespreking van die probleem). Ons het hier te doen met 'n geloofsgemeenskap wat in wording was. Dit is nie noodwendig dat Esra en Nehemia hierdie gemeenskap op dieselfde tyd geken het nie. Afhangende van die bepaalde teorie wat gehuldig word oor wanneer elkeen gekom en gegaan het, sal die bepaalde groep vir wie die gebed bedoel was beskryf word.

Vir die bepaling van die sosio-historiese konteks van die skuldgebed in Esra beteken dit dat ons verskillende moontlikhede het. Dit kan met 'n ander kring van denke te doen hê as die van Nehemia waarin die Gattung van die skuldgebed gebruik is om op sy eie bepaalde manier oor God te teologiseer. Dit kan selfs uit dieselfde kring afkomstig wees, maar 'n vroeëre of latere fase as die van die Nehemiagebed verteenwoordig. Albei deel dieselfde bedoeling. Die besonderhede kan egter van mekaar verskil oor die werklike inhoud van die verbode huwelike.

Die saak word verder problematiseer wanneer die inligting van Josefus in sy Oudhede XI, 306-312 in aanmerking geneem word. Volgens hom het Manasse, die broer van die hoëpriester Jaddua Jerusalem verlaat uit reaksie op Nehemia se hantering van die "gemengde huwelike". Sy skoonpa Sanballat, die Persiese goewerneur, het Manasse die hoëpriester gemaak van 'n nuwe tempel wat hy teen die einde van die vyfde eeu op die berg Gerisim in Samaria gebou het. Onder leiding van Sadokitiese priesters het hulle as teenvoeter vir die godsdiens by die tempel in Jerusalem gedurende die vierde eeu vC 'n eie kanon van heilige skrifte en 'n eiesoortige manier van 
aanbidding ontwikkel. Hoe feitelik korrek Josefus se inligting ook al is, duik die saak van die verskil oor huwelike hier ook op.

'n Derde been in die Judese gemeenskap duik op in die tradisies wat eventueel reflekteer word in die Boek van die Wagte (1 Henog 1-36), die boek Jubileë en die boek van Aramese Levi. Moontlik onder invloed van Fenisiese en Siriese tradisies het 'n stroming in die gebied van Galilea en die meer van Hule noord daarvan posgevat wat opsigtelik anti-Samaritaans, maar ook teen die tempelgemeenskap in Jerusalem was. Hierdie standpunt word in al drie die genoemde werke aangetref. Tigchelaar (1996:203) is van oortuiging dat die Boek van die Wagte basies 'n polemiek is teen die priesters in Jerusalem. Die opvallende ooreenkomste tussen Esra en 1 Henog 12-16 is 'n aanduiding dat die belangrikste saak in die Boek van die Wagte ook die is van "gemengde huwelike", spesifiek tussen priesters en nie-Joodse vrouens. Volgens Drawnell (2003) gaan die werk Aramese Levi uit die laat Persiese/ vroeg Hellenistiese tyd ook oor die priesters, hulle pligte en die huwelike wat hulle mag sluit. Volgens (Kugler 1996:225) het die fokus in Jubileë eerder geval op die ondertrouing van priesters buite hulle eie groep, hulle afkoms en hulle verwantskap aan Jakob. Al drie hierdie geskrifte dui aan dat daar in die laat-Persiese tyd 'n intense debat tussen verskillende groepe aan die gang was dwarsoor die Palestynse gebied oor die ware essensie van priesterskap.

Die konflik was miskien nog heelwat groter as bloot net die vraagstuk van ondertrouing. Die Moabitiese afkoms van Dawid word in die verhaal van Rut ingevleg en verintensiveer deur die byvoeging van 'n eksplisiete geslagslys in Rut 4:8-22. Die verhaal van Jona dui die inwoners van Nineve aan as die nie-Judese mense oor wie die Here ontferm. Ester vertel die diasporaverhaal van die Jode onder welwillende Persiese oorheersing. Daniël dien onder verskillende Galdese en Persies konings wat selfs God se almag erken. In al hierdie kortverhale uit die tweede tempel periode kom die vraagstuk na die verhouding tussen Judeërs en hulle buurvolkere na vore. Binne die groter omvang van die Ou Testament het ons dus hier te doen met 'n wye verskeidenheid van verskillende en selfs teenoorstaande standpunte.

\section{OPSOMMING EN TEOLOGIESE BETEKENIS}

Die skuldgebed was 'n genre in ou Israel wat by verskillende geleenthede gebruik is. Dit gaan in hierdie gebede basies oor die konseptualisering van die verhouding tussen God en Israel. Een strategie wat gevolg word is om 'n historiese oorsig oor die geskiedenis te gee. Saam met ander begrippe soos die land en die wet van God, word hierdie oorsig gebruik om die sondige geaardheid van Israel en die vergewingsgesindheid van God onder woorde te stel. 
Dit was egter veral tydens vasdae waarin die voorganger hierdie gebede in 'n liturgiese situasie gebid het. Hierdie oefening is binne ' $n$ kultiese konteks gedoen. Dit is gedoen voor gelowiges wat teenwoordig was. Dit het kennelik nie net gegaan om ' $n$ blote kultiese ritueel nie, maar om 'n geleentheid waarin die gelowiges in geloofsterme kon besin oor hulle identiteit voor God en in teologiese taal kon verbaliseer wat hulle van God glo.

In die gebed in Esra 9:6-15 kom al die tipiese elemente van die genre van die skuldgebed voor: lofprysing, smeking, belydenis van sonde en die onderwerpe land en wet. Soos in baie ander soortgelyke gebede, word hier ook gebruik gemaak van 'n stereotipe historiese retrospeksie van die geskiedenis van Israel. Die fases van woestyntog, ballingskap en terugkeer na die land word hier gebruik. Rondom die kernwoord "land" word die bewoning, prysgawe en herbewoning van die land deur die verloop van die geskiedenis gebruik om die sondige en ongehoorsame geaardheid van Israel en die volgehoue goedheid van God onder woorde te stel.

Die simmetriese struktuur van die gebed fokus op die oortreding van Israel en beskryf dit in spesifiek terme as hulle neiging om teen God se uitdruklike voorskrifte in met ander volkere te ondertrou. Dit ontsê hulle van alle aanspraak daarop om in die land te bly. In die lig daarvan word hulle terugkeer na die land en hulle sukses om die tempel te herbou en die kultus weer op die been te bring as ' $n$ stukkie genade gesien wat God aan hulle verleen het. Hulle self-evaluasie as mense wat ten spyte daarvan dat hulle die teendeel verdien, tog nog kan voortgaan om God te dien, word dan in die fokuspunt van die gebed ' $n$ strategie om Jahwe as God van geregtigheid te bely.

Hierdie belydenis word in die groter literêre konteks waarin die gebed staan, aan die geloofsgemeenskap en hulle aktiwiteite verbind. Die skuld/geloofsbelydenis kry nog voller betekenis daar waar die sake uitgevoer word wat vir die diens van God voorgeskryf is en waar Hy ontmoet word in die liturgiese gebeure. Hier sê die gemeente wie hulle voor God is en wie God teenoor hulle is. Belydenis van eie skuld loop hand aan hand met belydenis van die geregtigheid van God teenoor sy volk.

In die terugkeer na Jerusalem en die herbou van die tempel en die opbou van die godsdiensgemeenskap, speel die gebed en die liturgiese aktiwiteite waarin dit gebid word 'n sentrale rol. Dit gaan nie net om God se vergifnis nie, maar ook om voorkomende maatreëls in die gemeenskap. Huwelike met persone buite die binnegroep word as 'n bedreiging vir die voortbestaan van die groep gesien. Die huwelike word religieus evalueer en as 'n sonde teen God bestempel. Die skuldgebed word dus ook 'n program 
om die kohesie van die geloofsgroep te bevorder en hulle unieke identiteit te omlyn.

Die skuldgebed binne die omraming van die liturgie is dus 'n stuk teologiese kleinkuns waarin die identiteit van die geloofsgemeenskap in terme van hulle verhouding met die Here verwoord word. Hierdie verhouding word bedreig deur die kontemporêre gevaar van ondertrouing met buitegroepe wat die identiteit van die geloofsgroep sal beskadig. In intense debat met ander groepe sowel binne as buite Jerusalem kristalliseer 'n eie standpunt uit vir die tyd en die omstandighede waaronder die groep leef. Die bedreiging word egter nie net ekstern beleef as 'n lokval wat vir die gemeenskap gestel is nie, maar veral ook intern as 'n geneigdheid wat oor jare by die gemeenskap geleef het, wat aangehelp is deur die omstandighede van die land waarin hulle bly. In die lig van God se wette het hulle hulleself leer ken as mense wat inherent swak is en volledig afhanklik is van die omstandighede wat die Here vir hulle skep. In die teenbeeld van hulle swakheid staan die geregtigheid van hulle God wat binne die verhouding met sy volk gewys het dat Hy regverdig en billik is, maar ook getrou aan sy eie geaardheid om tog nog vir sy volk om te gee.

In die gebed van Nehemia 9:5b-37 gaan dit weer oor 'n ander diagnose van die omstandighede. Hier gaan dit oor kulturele transformasie. Daar moet 'n eie identiteit ontwikkel word binne die raamwerk van Pesiese oorheersing. Die Judeërs is slawe in hulle eie land. Binne hierdie omstandighede soek die godsdiensgemeenskap na die geskikte uitingsvorms vir hulle tyd en omstandighede om beslag te gee aan die identiteit wat hulle vir hulleself uitgemaak het by die lees en nadenke oor die wet van God. Hulle vind hierdie identiteit in hulle onderneming om godsdienssuiwerheid in stand te hou, God se feeste te hou en die tempelkultus in stand te hou. Wat in die gebed van Nehemia ooreenstem met die gebed van Esra is die berou wat uitgespreek word oor die gemeenskap se swakheid en hulle vreugde oor die onbegrensde trou en liefde van God. Hierdie berou en vreugde vorm ook daar die twee interaktiewe komponente wat in die selfbewussyn van hierdie gemeenskap hulle voortstu na voortdurende besinning en voortgaande transformasie (vgl Venter 1995). In hierdie skuldbelydenis word skuld geprofileer en teologies gekontekstualiseer deur dit ten nouste te koppel aan die belydenis van God se geregtigheid, barmhartigheid en genade (vgl Venter 1999).

Die skuldgebed in Daniël 9:4-19 word weer binne die raamwerk van 'n apokalips geplaas. Die raaklyn met die ander twee gebede is die gedagte dat God mense in verhouding stel tot God, mense wat hulle skuld voor God bely en vir God bly wag om die geskiedenis van die gelowiges te verander. Ook hier word die skuldgebed 'n manier om die geloof in God te verwoord in terme 
van 'n verhouding waarin God die God van geregtigheid is wat goed is vir mense ten spyte daarvan dat hulle ongehoorsaam en skuldig is (vgl Venter 2004).

Die skuldgebed is dus 'n element van die liturgie waarin die geloof in God in terme van die verhouding tussen 'n regverdige God en skuldige, afhanklike, mense verwoord word. Die gebed gaan nie primêr om iets van God te vra nie, maar om die identiteit van die geloofsgemeenskap in woord en gebaar uit te druk. Hierdie identiteit word binne 'n verhouding beleef waarin die Here die rol speel van een wat oor ander ontferm en mense wat in skuld en tegelyk genade voor die Here staan. Die verwoording van die verhouding maak gebruik van geloofstaal en uitdrukkings uit die heilige geskrifte. Dit staan ook ingebed in die bepaalde sosio-kulturele konteks waarin die gelowiges hulle bevind. Dit identifiseer eietydse bedreigings, soos ondertrouing, kulturele transformasie of krisisse rondom die heiligdom. Die identifisering van die probleme help om die ideale waarna gestreef word om die geloofsgemeenskap se identiteit uit te bou, onder woorde te bring. Die skuldbelydenis is na alles belydenis van die God in wie die gemeenskap hulle identiteit vind.

\section{Literatuurverwysings}

Blenkinsopp, J 1991. Temple and society in Achaemenid Judah, in Davies, P R (ed), Second temple studies I Persian period, 22-53. Sheffield: JSOT Press. (JSOT Suppl 117.)

Boda, J J 1999. Praying the tradition: The origin and use of tradition in Nehemiah 9. Berlin: Walter de Gruyter. (Beihefte für die alttestamentliche Wissenschaft 277.)

Boshoff, W 2005. New politics, new stories, new history: The Chronicler as historian for a new generation. Verbum et Ecclesia 26(1), 1-15.

Drawnel, $\mathrm{H}$ 2003. The Aramaic Levi autobiography: Text, translation, and commentary. Doktorale Verhandeling, http://www.pib.urbe.it/tesi/drawnel.html.

Eskenazi, T C1988. In an age of prose: A literary approach to Ezra-Nehemiah. Atlanta, GA: Scholars Press.

Eskenazi, T C 1993. Current perspectives on Ezra-Nehemiah and the Persian period. Currents in research: Biblical Studies 1, 59-86.

Farisani, E 2004. The composition and the date of Ezra-Nehemiah. OTE 17(2), 208230.

Grabbe, L 1998. Ezra-Nehemiah. London: Routledge.

Holmgreen, F C 1987. Israel alive again: A commentary on the books of EzraNehemiah. Edinburgh:The Handsell Press.

Kugler, R A 1996. From patriarch to priest: The Levi-Priestly yradition from Aramaic Levi to Testament of Levi. SBL Early Judaism and it Literature. Atlanta, GA: Scholars Press. 
Tigchelaar, E J C 1996. Prophets of old and the day of the end: Zechariah, the book of watchers and apocalyptic. Oudtestamentische Studien, namens het Oudtestamentisch Werkgezelschap in Nederland en België, Deel xxxv. Leiden: Brill.

Tollefson, K D \& Williamson, H G M 1992. Nehemiah as cultural revitalization: An anthropological perspective. JSOT 56, 41-68.

Thronveit, M A 1992. Ezra-Nehemiah. Louisville, KY: John Knox.

Venter, P M 1995. Die aard van die geloofsgemeenskap in Nehemia 9. HTS 51, 720731.

Venter, P M 1999. Bybelse teologie en skuldbelydenis. HTS 55, 533-562.

Venter, P M 2004. Constitualised space in Daniel 9. HTS 60, 607-624.

Weinberg, J P1992. The citizen-temple community. Sheffield:JSOT Press. (JSOT Suppl 151.)

Werline, R 2003. Defining penitential prayer. Paper prepared for the Society of Biblical Literature Consultation: Penitential Prayer: Origin, development and impact consultation. November 22, 2003, http://macdiv.ca/prayer.

Williamson, H G M 1987. Ezra and Nehemiah. Sheffield: Sheffield Academic Press. (Old Testament Guides.)

Williamson, HGM 1998. Ezra-Nehemiah. Dallas, TX: Word Books. (Word Biblical Commentary, 16.) 